\title{
THERMAL TREATMENT AND PHASE FORMATION IN ILLITE AND KAOLINITE BASED CLAYS FROM TROPICAL REGIONS OF BOLIVIA
}

\author{
E. Escalera ${ }^{1}$, M.-L. Antti ${ }^{1}$ and M. Odén ${ }^{2}$ \\ ${ }^{1}$ Division of Engineering Materials, Luleå University of Technology, 97187 Luleå, Sweden \\ ${ }^{2}$ Nanostructured Materials, Department of Physics, Chemistry and Biology, Linköping University, \\ 58183 Linköping, Sweden \\ E-mail: edwesc@1tu.se
}

The aim of this study was to compare the thermal behaviour of clays containing illite and kaolinite in different proportions. The clays contained small amounts of $\mathrm{K}$ and $\mathrm{Fe}$, acting as fluxing agents. [1] In order to investigate the phase formations during heating, the samples were run in a DSC from room temperature to $1300^{\circ} \mathrm{C}$. The thermal expansion of the different samples was determined by dilatometer measurements from room temperature up to $1100^{\circ} \mathrm{C}$. The phase formation was evaluated using XRD and SEM.

In all samples, most of the kaolinite dehydroxilated during heating up to $650^{\circ} \mathrm{C}$ while illite remained unchanged up to $950^{\circ} \mathrm{C}$. There was no influence of the $\mathrm{K}$ and $\mathrm{Fe}$ content on the dehydroxilation. At temperatures above $950^{\circ} \mathrm{C}$ metakaolinite formed leading to a spinel-type phase. [2] Furthermore, mullite was formed in the temperature interval $1050^{\circ} \mathrm{C}-1150^{\circ} \mathrm{C}$. This range of temperatures for the mullite formation depended on the amount of $\mathrm{K}$ and $\mathrm{Fe}$ in the samples. It was observed by XRD that most of the illite was transformed into a Si-rich spinel phase at $1050^{\circ} \mathrm{C}$, [3] and during further heating transformed into mullite. [4] An increased amount of illite in the clays slightly decreased the melting temperature. The dilatometer measurements showed expansion and shrinkage for the dehydroxylation and spinel-phase formation respectively. [5]

\section{REFERENCES}

1. P. Pialy, N. Tessier-Doyen, D. Njopwouo, J.-P. Bonne, Journal of the European Ceramic Society, 29, $2009,1579$.

2. P. Ptáček, D. Kubátová, J. Havlica, J. Brandštetr, F. Šoukal, T. Opravil, Thermochimica Acta, $204,2010,222$.

3. C. J. McConville, W. E., Lee, Journal of the American Ceramic Society, 88, 2005, 2267.

4. S. Ferrari, A.F. Gualteri, Applied Clay Science, 32, 2006, 73.

5. M. Seynou, Y. Millogo, R. Ouedraogo, K. Traore, J. Tirlocq, Applied Clay Science, 51, $2011,499$. 